\title{
BUSINESS GAMES OF OCCUPATIONAL SAFETY AND HEALTH AS TOOL MODELING THE PROCESS OF FUTURE STUDENTS PROFESSIONAL ACTIVITIES
}

\author{
S. M. Holopura \\ National University of Life and Environmental Sciences of Ukraine, Ukraine. \\ Correspondence of the authors: svgolopura@ukr.net. \\ Article history: Received: March 2019. Received in the revised form: April 2019. Accepted: August 2019. \\ Bibl. 17, fig. 1, tabl. 0 .
}

Abstract. The organization of the educational process of students of higher educational institutions in the discipline "Occupational safety" has certain features, due to the need for students to form a work-safety outlook. In addition to the traditional forms, training in the field of vocational disciplines should include active learning tools, in particular, business games that allow students to simulate the process of future professional activity of students in order to acquire their professional skills in the classroom training.

The purpose of the research is to develop and substantiate the methodology of conducting a business game "The procedure of investigation and accounting of accidents, occupational diseases and accidents at work", which will allow students to act independently in the simulated situation, to solve specifically formulated tasks and problems, to develop ways solution.

In this work, a step-by-step algorithm for accident investigation at work is developed, which will allow students to supplement and consolidate the knowledge acquired during the study of the theoretical course, to develop skills in working with normative-legal acts on occupational safety and with reference literature. At the same time, students adapt to the necessity of making some efforts in understanding the provisions of labor protection documents written in dry business language without explanation.

It is noted that the acquired knowledge should ensure the acquisition of skills for making informed decisions on the development of an accident plan, completing the N-1 investigation act and the ability to independently solve occupational safety issues, activate students' creativity and enhance job security.

Key words: bussiness game, occupational safety, industrial situation, accident, investigation algorithm, optimal solutions.

\section{Introduction}

In the modern society, the main task of higher education is to train highly qualified specialists, individuals capable of self-development and self-realization in life. In higher education, business game is widely used as an important didactic method, which intensifies the learning process and closely links it with practical activity. The business game is based on the simulation model [1-5], which is realized due to the actions of the game participants. At seminars with the practical use of game technology is deepening and consolidation of students' knowledge, the ability to apply them in practice, to make collective decisions, to align their interests with the interests of the team in achieving common goals. Business play enables students not to be afraid of mistakes and to activate their own creative potential [6].

\section{Formulation of problem}

The inconsistency of the communication skills of future professionals, their ability to effectively solve problems in various fields of professional activity, with due regard to the requirements of occupational safety and health, and health, and the role in this process of business games have determined the direction of our research. Note that the business game is aimed at developing the ability to analyze specific practical situations and solve professional problems, during the game develops creative thinking, as well as honing the ability to communicate with colleagues and increase students' motivation to learn safety standards.

\section{Analysis of recent research results}

The basis of the use of any methodology in the study of occupational safety disciplines is a comprehensive methodological support of the educational process. Each teacher works on creation of it: planning, development and creation of the optimal system (complex) of educational-methodical documentation, teaching aids necessary for ensuring a complete and qualitative process of teaching of students of professions within the content and time determined in accordance with the curricula and programs [7].

One of the promising methods of training experienced professionals capable of making decisions to solve complex production issues is the development and conduct of business games [8]. The development of game forms and methods of using the game in the professional 
training of the future specialist were held by: L. Vygotsky, A. Verbitsky, B. Likhachev, T. Khlebnikova, G. Selevko, E. Khrutsky and others. In the works of L. Vygotsky, V. Platov argues that the business game is a pedagogical tool and an active form of learning, which shapes educational activities and develops professional skills [9]. G. Abramova, V. Stepanovich, emphasize that business play is an important condition for stimulating interest in knowledge $[10,5]$, a method of active learning that contributes to the achievement of specific tasks, structuring the system of business relationships of participants. Its structural elements are the design of reality, the conflict of the situation, the activity of the participants, the appropriate psychological climate, interpersonal and inter-group communication, the solution of problems formulated at the beginning of the game, which as a result creates conditions for improving the effectiveness of the learning process [11]. In particular, L.M. Sekacheva [12] believes that, when preparing future specialists, teachers should strive not only to equip students with scientific knowledge, but also to promote the development of practical efficiency and entrepreneurialism in them, to develop the skills of active thinking. Therefore, in his opinion, it is important to conduct educational business games with students that to some extent imitate professional situations.

The study of the essential characteristics of a business game based on the analysis of numerous publications [1-12] can be argued about the advantages of this form (method) of training. Business game activates participants, their mental and cognitive activity, develops skills of independent research and evaluation of information, as well as the ability to find new sources of obtaining the necessary information to achieve the goal. It motivates participants to make optimal decisions in their professional activities, including in the conditions of uncertainty, develops the ability to simulate a problematic situation, identify the cause and effect relationship between events and phenomena, forms analytical thinking, the ability to clearly and convincingly present their point of view, increases qualification of specialist. A business game reduces the number of mistakes made in practice, in professional activity as a result of the acquired knowledge and acquired skills [13].

Equally important is the task of communicative nature, because the learning process takes place in the context of communication between the teacher and the student. In particular, Y.V. Lebedev describes the use of an innovative approach in higher education as a process of improving pedagogical technologies, a set of methods, techniques and teaching aids [14]. The widespread "classic" chalk-and-talk training method is not effective enough nowadays because it is usually passive. Therefore, the scientist proposes to apply interactive methods of teaching students in higher education institutions, which help to create more comfortable learning conditions, under which the student feels his / her intellectual development and success, which makes the learning process effective.

The education system requires reforming and adapting to current requirements and international standards [15]. Among the available teaching methods that contribute to the ability to ensure the acquisition of these quali- ties by professionals is a business game, provided the use of traditional and innovative technologies that motivate the student to be an active subject of education and raise personal interest in the results of the acquired knowledge and acquired skills.

\section{Purpose of research}

To develop and substantiate the method of conducting a business game "Procedure for investigation and accounting of accidents, occupational diseases and accidents at work", which will allow students to act independently for a time under the simulated situation, to solve specifically formulated tasks and problems, to develop ways of solving them.

\section{Results of research}

Higher education institutions are a leading element in the formation of a complex of knowledge and skills in the field of occupational safety, since it is the level of education and awareness that largely determines the level of personal safety culture. It should be noted that the teaching of the discipline of "Occupational safety" has certain features, the main component is a large number of regulations governing labor law, sanitary and technical standards, industrial sanitation and safety, which prevent effects of harmful and dangerous factors on employee during work activity.

At the same time, in the educational and professional plans for training specialists, the discipline of "Occupational safety" is transferred to the category of nonnormative, combined with the discipline of "life safety", and significantly reduced the number of learning hours, which has a negative impact on the formation of a culture of safety for future professionals. In such conditions, the important task of teachers, during the preparation of specialists, is to find effective ways, methods and means of activating educational process in order to form the basis of a work-based outlook for students, oriented to the implementation of effective professional activity through the formation of responsibility for personal and collective safety, and awareness of the need for full implementation of all measures that guarantee the safety and hygiene of the workplace.

For the national higher education, the traditional approach to teaching is an object-oriented approach, where objects and phenomena rather than problems are offered for the sake of learning. But it should be emphasized that this approach shows poor efficiency, as it does not contribute to the systematic solution of problems arising in the field of human health activities. The formation of students not only the ability to solve professionallyoriented tasks, but also the willingness to make responsible decisions, the ability to creative level of their own professional activity is ensured by applying a subjectactivity approach [12]. This approach allows you to transform a student from an object into a subject of study, to create the most favorable conditions for the development and reveal of his abilities, orientates not only the assimilation of knowledge, but also the ways of this assimilation, 
thinking and activity, the development of cognitive forces and creative student's potential. However, given the peculiarities of the discipline, and the general tendencies to reduce the volume of classroom work and increase the amount of time spent on independent work of the student, this approach in practice is quite difficult to implement.

Taking into account global trends, Ukrainian higher education is consistently switching to the use of "third generation" higher education standards, based on the development of a competent approach, as one of the new conceptual guidelines, directions of development of educational content in Ukraine and developed countries [13].

As noted above, the hallmark of a business game is the presence of a simulation model. The structure of a business game includes the following main stages: preparatory, conducting the game, analyzing and summarizing its results. [14] Development begins with defining the purpose and objectives of the game, formulating requirements for players. The purpose of the game has two aspects: motivational and didactic.

Let's consider a step-by-step algorithm for investigating workplace accidents that was conducted with college students. After studying the topic: "Investigation procedure and accounting for accidents, occupational diseases and industrial accidents" and familiarization with the provisions of LAOS 0.00-6.02-19 (Legal act on Occupational safety), offer a production situation with a description of the circumstances of the accident in accordance with the application "Input data of business games". Students are formed to investigate the production situation, determine the duties, functions and rights of each member of the commission. Each group is provided by LAOS $0.00-6.02-19$, forms of primary documentation on safety, photos, posters, schemes of the scene of the accident, task forms.

A plan of an investigation into the proposed example of an industrial accident is outlined. Formed groups of students are invited to investigate the production situation that led to the accident, record the information received on the form of the act of investigation, encode it, sign the act by members of the commission. Groups of participants should analyze the degree of completeness and objectivity of the investigation process for the proposed game situation and make conclusions about the completion of the investigation, register the accident in a special journal, prepare a draft order of the head of the company on measures to prevent accidents in the structural subdivision, where the accident took place.

Stages and sequence of conducting a business game (fig. 1). The teacher gives general tasks for conducting business game and proposes to organize subgroups. Each member of the subgroup must carry out the activities of the employee of the company according to the list of duties outlined in the LAOS 0.00-6.02-19. The members of the commission shall choose the functions of the members of the business game independently.

During the investigation of an accident, each subgroup (commission) makes its own decision: to supplement the missing information; identification of the circumstances of the accident, the type of event and its cause; measures to eliminate the causes of the accident; and the executors of the proposed activities and timing; persons guilty of violating labor law and labor safety standards.

Stages and sequence of conducting a business game.

Stage I. Introduction to the game situation.

Each subgroup of students receives initial information about the game situation (circumstances in which the accident occurred).

Stage II. Establishing the causes of an accident. Students, using regulatory documentation (LAOS 0.00-6.0219) and general accident information, model the accident investigation.

In conducting the investigation, attention should be paid to the following points:

1) to ascertain the objective conditions under which the accident occurred, its suddenness and the duration of the event (instantaneously or for some time), whether it was possible to prevent a work injury; establish the circumstances and nature of the accident;

2) to nominate and check the versions of the causes of the accident on the basis of discussion of general information about the event;

3) to evaluate the level of organizational work on occupational safety at the enterprise and in the unit where the accident occurred: the presence (or absence) of company head's order on the responsibility of officials for the state of occupational safety at the enterprise; training of workers on labor protection issues; compliance of the existing state of workplace safety with the requirements of normative documentation on labor protection; provision of workplaces with instructions on safety, visual means of promoting safe methods of work execution; the use of collective and individual protection of workers from the effects of dangerous and harmful factors of production, etc.;

4) record information about the victim: gender, age, qualification and experience of work, availability of a document for the right to work at the object of trauma, health status - conclusion of medical examinations, contract for performance of work, etc.;

5) describe the technical condition of the technological equipment (machines, equipment, devices, etc.), whether they meet the safety requirements, whether there is technical documentation, what is the periodicity of maintenance, the degree of wear;

6) to assess compliance of sanitary and hygienic working conditions in the structural subdivision with normative documents on labor protection;

7) to classify the relationship of the event type with the working conditions (according to the LAOS 0.006.02-19).

Stage III. Preparation of accident documentation. Once the game situation data is received, the members of the commission of inquiry established discuss the available accident information. A sub-group (commission) of students should develop a plan of action to address the causes of the accident. To this end, each student submits proposals to an action plan based on their functional responsibilities as a member of the inquiry committee. Then, in the subgroup discuss the developed measures, fill in the items of the act of inquiry in the form of $\mathrm{N}-1$, determine whether or not an accident related to the production. If an accident is considered production related, it is denoted by a capital letter $\mathrm{P}(\mathrm{N}-1 / \mathrm{P})$, if not production 
related, by capital letters NP (N-1/NP). Identify workersviolators of labor safety standards.

Stage IV. General discussion of the results of the third stage of the investigation. The decisions taken are discussed between the commissions (sub-groups) or be- tween the representatives of the sub-groups (members of the commission). Each subgroup offers its own version of the investigation materials, substantiates its decisions included in the act of investigation.

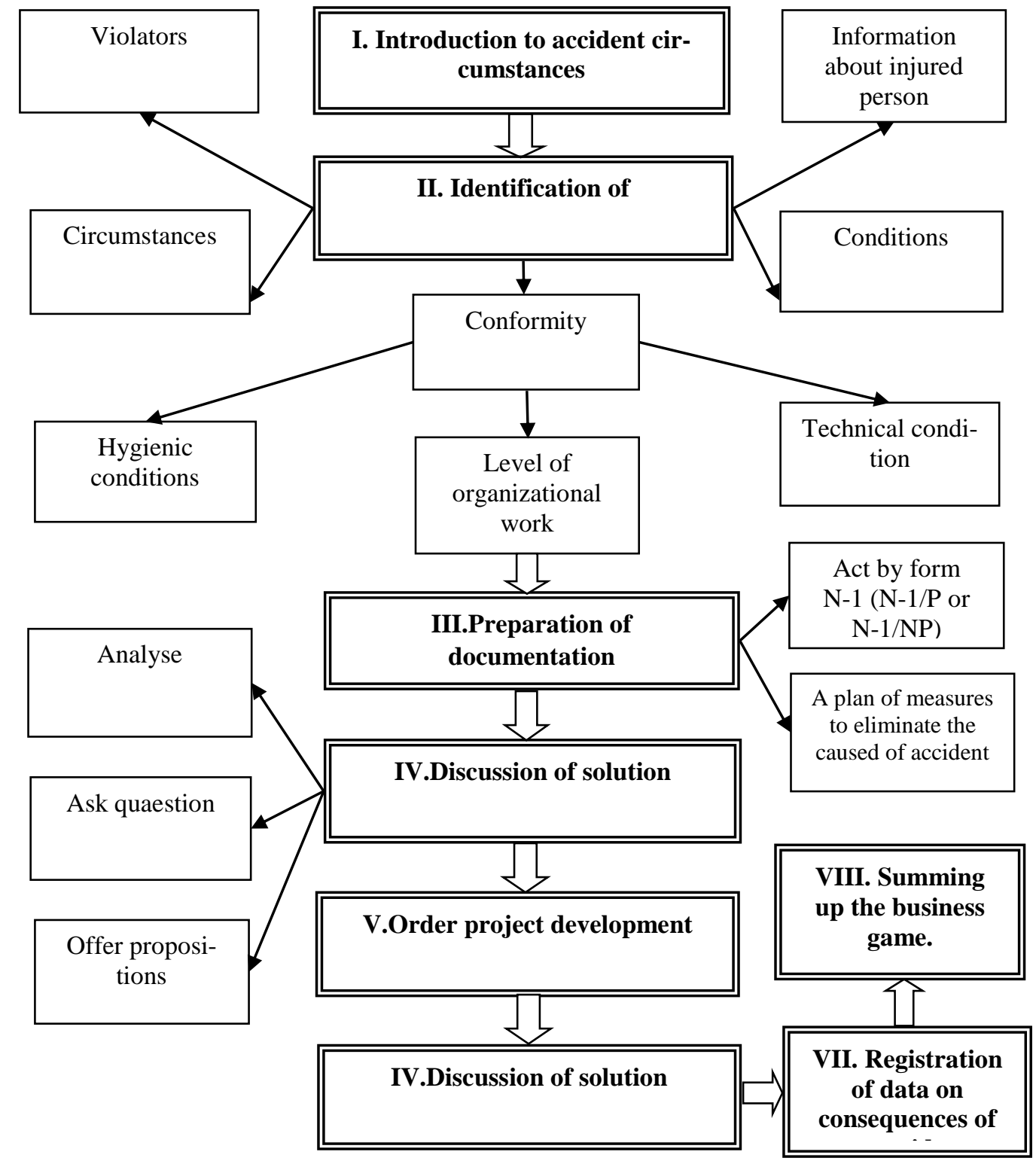

Fig. 1. Stages and sequence of conducting a business game "Investigation procedure and accounting for accidents, occupational diseases and industrial accidents".

Business game participants analyze the content of speeches, ask questions, make suggestions for changes to the text in conflicting points of the act of investigation.

Stage V. Developing a draft accident order. Students develop a draft order based on the results of the investigation, discuss it in subgroups and submit it to the manager of the business game.

Stage VI. Registration of item 9 of the act of investigation in the form $\mathrm{N}-1$. Students are provided with additional information that describes the consequences of the accident. The subgroups complete paragraph 9 of the N-1 investigation act and discuss the consequences of completing the steps.

VII stage. Registration of materials on consequences of an accident. In each subgroup, the certificate of the consequences of an accident with the victim is drawn up in the form of a form corresponding to the logbook for the account of accidents, and also fill in paragraphs $4-7$ of the act of inquiry in the form N-1.

VIII stage. Summing up the business game. The results of the business game are conducted by the teacher. Based on the established criteria, he evaluates the work of subgroups and each student. Draws general conclusions about conducting a business game based on the points received by each participant and gives each student an assessment. The report of the participant of the game for the completed work (business game) is a properly executed act in the form of $\mathrm{N}-1$ on a specific accident with the signature of all members of the commission. Having checked the correctness of the registration of the act of 
investigation, the teacher signs it on the first page of the document in the stamp "Approved".

Developed business game "Procedure for investigation and accounting of accidents, occupational diseases and accidents at work" will facilitate the acquisition of skills in working with normative legal acts on occupational safety and reference literature, the ability to independently solve the issues of occupational safety, gain experience and study experience, developing a plan of action to address the causes of an accident in making decisions to prevent injury to employees. Manufacturing practice shows that only the knowledge that a student has gained through his or her own experience, search and understanding becomes his or her property [7]. The task of the business game in the field of labor protection disciplines is to supplement and consolidate the knowledge acquired during the study of the theoretical course of labor protection, to activate the creativity of students.

\section{Conclusions}

1. Developed and grounded methodology of business games "Procedure for investigation and accounting of accidents, occupational diseases and accidents at work" in the process of teaching students will provide an opportunity to combine theoretical knowledge in practice, the speed of learning new skills, the ability to make independent decisions.

2. The described method of preparation and conduct of a business game can be used as one of the active methods of teaching, which allow students to act independently in the simulated situation. Analysis of the development of the situation, different ways of solving it, actions, methods and ways of solving critical situations contributes to a significant improvement of the quality of the educational process and the accumulation of experience.

3. The use of business games in the classroom will help to identify weaknesses and gaps in knowledge, building confidence in their skills, reducing the psychological barrier and accelerating adaptation in production conditions, the formation of internal need and importance in training.

\section{References}

1.Lipkovich I. E., Taran E. A., Orischenko I. V. (2015). Business games: a textbook: Azov-Black Sea Engineering Institute in Zernograd. Zernograd. 63.

2.Rogozhin, M. Y. Occupational safety in educational organizations. Moscow. Alpha - Press, 2013. 400.

3.Vanyushin $\quad$. N., Gvozdikov S. V., Lavrentyev A. R., Orlova L. A. (2015). Businessgame in training: a scientific and practical search. Dzerzhinsk: Kon-Cord Publishing House. 131.

4.Orlova L. A. (2015). Law and Rules of the Game: Monograph, ed. Doctor of Law, prof. V.M. Baranova. Moscow. Yurlitinform Publishing House. 230.

5.Dereza O. O., Dereza S. V. (2017). Business Game and its Possibilities in the Professional Training of Future Engineers. Collection of scientific and methodological works: Improvement of the educational process in higher education. No. 20. Melitopol. 100-105.

6. Surgova S. Yu. (2018). Using a business game in the process of forming the creative personality of future social workers. Pedagogy of formation of creative personality in higher and general education schools: Coll. Sciences. BC Zaporozhye: KPU. Issue. 60. T. 2. 168-172.

7. Voloshina O. I. (2015). Formation of professional skills in the process of independent work of students. Scientific notes. Series: Problems of Methods of Physical, Mathematical and Technological Education. Issue. 7 (I). 121-124.

8.Zel'dovich B. Z. (2011). Business games in the management of printing and publishing processes: textbook. manual; Mosk. state. their ovens. Ivana Fedorova. Moscow. MGUP them. Ivan Fedorova. 232.

9. Oliynyk N. A. (2018). Teaching Methods of Future Agro-Engineers. Pedagogics of Creating Creative Personality in Higher and General Education Schools: Coll. Sciences. BC - Zaporozhye: KPU. Issue. 60. vol. 2. 134138.

10. Vasilenko O. V. (2015). Experience of application of modern methods of training in the preparation of specialists of restaurant business in higher educational establishments. Scientific Notes. Series: Problems of Methods of Physical, Mathematical and Technological Education. Issue. 7 (I). 118-121.

11. Litvinov A. S. (2017). Pedagogical Provision of Innovations in Education: Educ. manual for the general Sciences. ed. ped. Prof. V.V. Borisova. Sumy. University Book. 265.

12. Litvinov A. S. (2017). Pedagogical Provision of Innovations in Education: Educ. manual for the general Sciences. ed. ped. Prof. V.V. Borisova. Sumy. University Book. 265.

13. Zakharenko V. O., Yurchenko M. A. (2018). Quality of education, problems and directions of solution of questions of training of specialists. Modernization of higher education and problems of management of quality of training of specialists. Organization of the system of interaction. KhDUKHT. 155-156.

14. Lebedeva Y. V. (2015). Problems of implementation of innovative technologies in the educational process of the university. Professional education in the modern world. No. 2 (17). 146-158.

15. Gorelkov D. V., Chervony $\quad$ V. M., Dmitrevsky D. V., Chervony M. V. (2018). Improving the effectiveness of quality management of interaction in the system of "higher technical education - business". Modernization of higher education and the problems of quality management training of specialists. Organization of the system of interaction "higher education - the labor market. KhDUKHT. 135-136.

16. Chorna O. G. (2015). Topical problems of teaching the disciplines of the cycle of life safety in modern conditions. Didactics of physics as a conceptual basis for the formation of competence and outlook qualities of a future specialist of physical and mathematical profile: collection of materials of the $\mathrm{X}$ International: scientific conference. Kamianets-Podilsky: LLC "Ruta Printing House". 172. 117-119.

17. Safranov T. A., Lukashov D. V., Shelest Z. M., Vladimirova O. G., Chugay A. V. (2017). Standards of 
higher ecological education of Ukraine: current state and problems of implementation. Bulletin of KhNU $\mathrm{N}$. Karazin series "Ecology", issue. 16. 141-149.

\section{Список літератури}

1.Lipkovich I. E., Taran E. A., Orischenko I. V. Business games: a textbook: Azov-Black Sea Engineering Institute in Zernograd. Zernograd, 2015. 63 p.

2.Rogozhin, $M$. $Y$. Occupational safety in educational organizations. Moscow. Alpha - Press, 2013. 400 p.

3.Vanyushin $\quad V . \quad N ., \quad$ Gvozdikov $S . \quad V$., Lavrentyev A. R., Orlova L. A. Businessgame in training: a scientific and practical search. Dzerzhinsk: Kon-Cord Publishing House, 2015. $131 \mathrm{p}$.

4. Orlova L. A. Law and Rules of the Game: Monograph, ed. Doctor of Law, prof. V.M. Baranova. Moscow. Yurlitinform Publishing House, 2015. 230 p.

5.Dereza O. O., Dereza $S$. V. Business Game and its Possibilities in the Professional Training of Future Engineers. Collection of scientific and methodological works: Improvement of the educational process in higher education. No. 20. Melitopol, 2017. P. 100-105.

6.Surgova $S$. Yu. Using a business game in the process of forming the creative personality of future social workers. Pedagogy of formation of creative personality in higher and general education schools: Coll. Sciences. BC Zaporozhye: KPU, 2018. Issue. 60. T. 2. P. 168-172.

7. Voloshina $O$. I. Formation of professional skills in the process of independent work of students. Scientific notes. Series: Problems of Methods of Physical, Mathematical and Technological Education, 2015. Issue. 7 (I) P. 121-124.

8.Zel'dovich B. Z. Business games in the management of printing and publishing processes: textbook. manual; Mosk. state. their ovens. Ivana Fedorova. Moscow. MGUP them. Ivan Fedorova, 2011. 232 p.

9. Oliynyk N. A. Teaching Methods of Future AgroEngineers. Pedagogics of Creating Creative Personality in Higher and General Education Schools: Coll. Sciences. BC - Zaporozhye: KPU, 2018. Issue. 60. vol. 2. P. 134138.

10. Vasilenko $O$. V. Experience of application of modern methods of training in the preparation of specialists of restaurant business in higher educational establishments. Scientific Notes. Series: Problems of Methods of Physical, Mathematical and Technological Education, 2015. Issue. 7 (I). P. 118-121.

11. Litvinov A. S. Pedagogical Provision of Innovations in Education: Educ. manual for the general Sciences. ed. ped. Prof. V.V. Borisova. Sumy. University Book, 2017. 265 p.

12. Litvinov A. S. Pedagogical Provision of Innovations in Education: Educ. manual for the general Sciences. ed. ped. Prof. V.V. Borisova. Sumy. University Book, 2017. 265 p.

13. Zakharenko V. O., Yurchenko M. A. Quality of education, problems and directions of solution of questions of training of specialists. Modernization of higher education and problems of management of quality of training of specialists. Organization of the system of interaction. KhDUKHT, 2018. P. 155-156.
14. Lebedeva $Y$. V. Problems of implementation of innovative technologies in the educational process of the university. Professional education in the modern world. 2015. No. 2 (17). P. 146-158.

15. Gorelkov D. V., Chervony $\quad$ V. M. Dmitrevsky D. V., Chervony $M$. V. Improving the effectiveness of quality management of interaction in the system of "higher technical education - business". Modernization of higher education and the problems of quality management training of specialists. Organization of the system of interaction "higher education - the labor market. KhDUKHT, 2018. P. 135-136.

16. Chorna $O$. G. Topical problems of teaching the disciplines of the cycle of life safety in modern conditions. Didactics of physics as a conceptual basis for the formation of competence and outlook qualities of a future specialist of physical and mathematical profile: collection of materials of the X International: scientific conference. Kamianets-Podilsky: LLC "Ruta Printing House", 2015. 172 p. P. 117-119.

17. Safranov T. A., Lukashov D. V., Shelest Z. M., Vladimirova O. G., Chugay A. V. Standards of higher ecological education of Ukraine: current state and problems of implementation. Bulletin of KhNU N. Karazin series "Ecology", issue. 16. 2017. P. 141-149.

\section{ДІЛОВІ ІГРИ 3 ОХОРОНИ ПРАЦІ В ЯКОСТІ \\ ІНСТРУМЕНТУ МОДЕЛЮВАННЯ ПРОЦЕСУ ПІДГОТОВКИ МАЙБУТНІХ СТУДЕНТІВ ПРОФЕСІЙНОЇ ДІЯЛЬНОСТІ \\ С. М. Голопура}

Анотація. Організація навчального процесу студентів вищих навчальних закладів 3 дисципліни охорона праці має певні особливості, у зв'язку 3 необхідністю для студентів у вигляді роботи безпеки в Outlook. Крім традиційних форм навчання у сфері професійної дисципліни повинен включати активні засоби навчання, зокрема ділові ігри, що дозволяють студентам моделювати процес майбутньої професійної діяльності студентів 3 метою набуття професійних навичок у класі навчання.

Мета дослідження полягає в розробці та обгрунтуванні методики проведення ділової гри порядок розслідування та обліку нещасних випадків, професійних захворювань і аварій на виробництві, який дозволить студентам самостійно діяти у змодельованій ситуації, для вирішення конкретно сформульованих задач і проблем, розробити шляхи вирішення.

В даній роботі пропонується покроковий алгоритм розслідування нещасного випадку на виробництві, яка дозволить студентам доповнити i закріпити знання, отримані при вивченні теоретичного курсу, розвиток навичок роботи 3 нормативно-правовими актами 3 охорони праці та довідкової літератури. У той же час, студенти адаптуються до необхідності робити якісь зусилля в розумінні положень 3 охорони праці документи, написані в сухому діловій мові, без пояснення причин.

Відзначається, що отримані знання повинні забезпечуватися придбання навичок для прийняття обгрунтованих рішень про розвиток аварії план, за- 
вершуючи Н-1 акт розслідування і здатність самостійно вирішувати питання охорони праці, активізувати творчі здібності учнів і підвищити безпеку роботи.

Ключові слова: бізнес-ігри, техніки безпеки, виробничої ситуації, аварії, алгоритм розслідування, оптимальних рішень.

\section{ДЕЛОВЫЕ ИГРЫ ПО ОХРАНЕ ТРУДА В КАЧЕ- СТВЕ ИНСТРУМЕНТА МОДЕЛИРОВАНИЯ ПРО- ЦЕССА ПОДГОТОВКИ БУДУЩИХ СТУДЕНТОВ ПРОФЕССИОНАЛЬНОЙ ДЕЯТЕЛЬНОСТИ С. Н. Голопура}

Аннотация. Организация учебного процесса студентов высших учебных заведений по дисциплине охрана труда имеет определенные особенности, в связи с необходимостью для студентов в виде работы безопасности в Outlook. Помимо традиционных форм обучения в области профессиональной дисциплины должен включать активные средства обучения, в частности деловые игры, позволяющие студентам моделировать процесс будущей профессиональной деятельности студентов с целью приобретения профессиональных навыков в классе обучения.

Цель исследования заключается в разработке и обосновании методики проведения деловой игры порядок расследования и учета несчастных случаев, профессиональных заболеваний и аварий на производстве, который позволит студентам самостоятельно действовать в смоделированной ситуации, для решения конкретно сформулированных задач и проблем, разработать пути решения.

В данной работе предлагается пошаговый алгоритм расследование несчастного случая на производстве, которая позволит студентам дополнить и закрепить знания, полученные при изучении теоретического курса, развитие навыков в работе с нормативноправовыми актами по охране труда и справочной литературы. В то же время, студенты адаптируются к необходимости делать какие-то усилия в понимании положений по охране труда документы, написанные в сухом деловом языке, без объяснения причин.

Отмечается, что полученные знания должны обеспечиваться приобретение навыков для принятия обоснованных решений о развитии аварии план, завершая Н-1 расследования акт и способность самостоятельно решать вопросы охраны труда, активизировать творческие способности учащихся и повысить безопасность работы.

Ключевые слова: бизнес-игры, технике безопасности, производственной ситуации, аварии, алгоритм расследования, оптимальных решений.

\section{S. M. Holopura ORCID 0000-0001-9531-5344}


